\title{
Sri Lankan Tamil Refugees in India
}

\author{
Asha Hans
}

\section{Background}

A poet once described Sri Lanka as a tear dropped from the Indian face. Today the land, awash with unending violence, epitomizes this description. The ravaged island and its link to India remains unbroken by the presence of approximately 200,000 Sri Lankan refugees in India.

The discrimination and violence by the Sri Lankan state against the Tamils throughout the 1950s, 1960s and 1970s form the backdrop to this refugee situation. As the crisis deepened, small numbers of Sri Lankan Tamil educated elite migrated. The majority went to the developed West, the rest to neighbouring India. The expatriate community swelled and would in time provide sustenance to the movement.

In 1983, theSinhalese violence against the Tamils and Tamil insurgency resulted in the displacement of all communities in the north and the east. These included the Tamils, Tamil-speaking Muslimsand Sinhalese settled in the east. India, for security reasons, could not overlooksuch political developments. Its fears were not unfounded, for the next step was the exodus_crossing the narrow Palk Straits-into India.

All the refugees who came to India in 1983 took refuge in the state of Tamil Nadu, with a population of $55,638,318$ (1991 provisional census). By the early part of 1993, there were an estimated 200,000 Sri Lankan Tamils. There is no exact number available as many do not register, despite local government orders. It is easy to remain undetected with many refugees living outside the camps.

\footnotetext{
is

Professor Hans teaches at the Postgraduate School of Political Science, Utkal University, Orissa, India. This article is from her forthcoming monograph on the same subject, to be published by York Lanes Press, Toronto.
}

The 8,0241 camp refugees are all registered, as are the 1,714 in special camps. In outside camps 27,000 have been registered. Despite threats of deportation and internment in special camps since 1993, the rest remain unregistered. The basic problem is the refugees fear of being branded militants and being deported or interned in the special camps.

\section{The Camps}

When the first wave of refugees entered India in 1983, they were divided into three groups. Besides the camp and noncamp refugees, there were the militants in special camps (Mohandas 1992; Karunanidhi 1990).

- The Refugee as Militant: Militant leadership has always been elitist and there is a clear line of distinction between them and the mass of refugees. The leadership drew its support and recruited its forces from the refugee camps. These camps no longer exist. They were all closed down after the assassination of Rajiv Gandhi, but their legacy continues to haunt the refugees.

- Noncamp Refugees: These are the refugees who do not receive financial assistance from the government. They are mostly rich businessmen and professionals. They also include a small number of near destitute young men who are in India to escape from being recruited by the militants. Since Gandhi's assassination, noncamp refugees have been moved into the camps for security reasons or have gone underground for fear of being interned in special camps.

- Ordinary Camp Refugee: There are 132 camps in Tamil Nadu and one in Orissa. All refugees in camps are registered. This entitles them to government assistance-cash, shelter, health facilities, clothing and provision of essential items. The refugees from Sri Lanka have been the recipients of one of the most advanced systems of education in the world, but since 1991, this privilegehas been withdrawn. There is no uniformity in the camp facilities. Some are good, some are unsatisfactory. In the same way, the reception from some locals is good while others are hostile. Women have a number of social and psychological problems that continue and increase with time.

\section{The Militant as Refugee}

With increasing militant activities in the state, in March 1990 Tamil Nadu refused to grant asylum to 1,638 Tamil Eelam Liberation Organisation (TELO), Eelam National Democratic Liberation Front (ENDLF) and Eelam People's Revolutionary Liberation Front (EPRLF) cadres. They were then sent to Malkangiri in the state of Orissa. Today only the ENDLF members remain in this camp.The 200 remaining refugees are very young. They have came from Trincomalee and Batticaloa. They are all in their twenties, and according to the security guards posted outside the camp, can dismantle and assemble a gun in seconds. According to them they have all been trained by the Indian security forces. They are an army in waiting. When the right moment comes, they will, like their predecessors, escape away in the night.

Their lifestyle is similar to that of the ordinary camp refugee in Tamil Nadu. The reason for providing a view of the militant camp is to show that the dividing line between the refugee and the militant is very thin indeed when it comes to the rank and file. It is the militant leadership as mentioned earlier which is totally different. The mass of militants face the same problems as all refugees. The only difference is the fervour and the sparkle in the eyes of the men. Immaculately dressed, they do not have the mark of a downtrodden humanity. 


\section{Aid From NGO's}

No aid is asked of the United Nations High Commissioner for Refugees (UNHCR) orvoluntary agencies forrefugee rehabilitation in India. The central government provides the finances and the state, the infrastructure. India does not encourage international NGO's to work in the camps except the Red Cross (local branch). The only organizations allowed to work are those run by the refugees themselves. In the Sri Lankan camps, the largest voluntary organization working with the refugees is OFERR (Organisation for Eelam Refugee Rehabilitation). It is run by S.C. Chandrahasan, the son of the late Sri Lankan Tamil leader, S.J.V. Chelvanayagam. The working of this organization proves the effectiveness of refugee NGO's vis-à-vis international NGO's and the need for refugee leadership. Refugee NGO's know the needs of their people and leadership is a requisite to coordinate activities.

\section{Forced Repatriation}

Repatriation of Sri Lankan refugees took place in 1987 and 1991. The first repatriation took place after the signing of the Indo -Sri Lanka Peace Accord in 1987. It was voluntary in nature. After the first repatriation most of the camps were closed down (Public [Refugees] Rehabilitation Department 1987, p.6), The assassination of former Indian Prime Minister Rajiv Gandhi, on May 21, 1991, prompted the Indian government to repatriate the refugee. For a year attempts at forcing the refugee to go back were made. The policy was ambivalent, not uniform and carried out by local officials. In some camps the refugees were explained about the process of repatriation, given the option to stay and forms in Tamil were distributed. In other camps no explanation was offered. Some refugees signed the form without realizing what it meant because it was given by the officers who distributed the cash assistance. Others who did understand that it was a returnee form signed it under pressure from the officer concerned under a threat that if they did not do so, no further assistance would be given. As a result
30,000 signed the repatriation consent forms.

India, which had never turned back genuine refugees, or used force in repatriation blotted its record in this case. The reasons were not related to any formal change in policy towards refugees. It was a reaction to the assassination of its Prime Minister. According to the Sri Lankan refugee it reflected the view that "unless all Ceylon Tamil Refugees were repatriated, the activities of the LTTE could not be curbed in India." The answer was not so simple. Increasing militancy and the assassin being aSriLankan were the catalyst in a complex situation of national politics.

\section{The Entry of the UNHCR}

India is not a signatory to the UN Convention on Refugees, and the UNHCR has notbeen allowed to work in India. During the Tibetan crisis in 1959, and the Bangladesh crisis of 1971, the only help taken from UNHCR was financial. But in a surprise move on the July 27, 1992 India signed a Memorandum of Understanding with the UNHCR.

Before the entry of the UNHCR, the Government of India had repatriated 23,126 persons between the January 20 ,
1992 and May 15, 1992 (UNHCR). Though it has the legitimacy to work from Indian territory and opened its first office in India, in Madras, it is on a very limited mandate. Sunil Thapa, the Repatriation officer who had earlier worked in the UNHCR operation in Sri Lanka, said that at that moment their work was confined to interviewing refugees. All those who signed the returnee forms are interviewed in Transit camps to ascertain whether the repatriation is forced or voluntary. UNHCR has no financial commitment. All financial help in repatriation to the refugee comes from the Government of India.

It is obvious that the UNHCR presence has deterred any forcible repatriation. At the same time it cannot be overlooked that of the 2,938 persons screened by UNHCR only 90 withdrew their applications for repatriation (UNHCR). Thus no general conclusion can be drawn that total repatriation was forced, a number of refugees did go back voluntarily. UNHCR officials now wait in Madras for repatriation to restart but the refugees are not interested in going back. The channels of communication open through their network show a very confused scene in Sri Lanka.

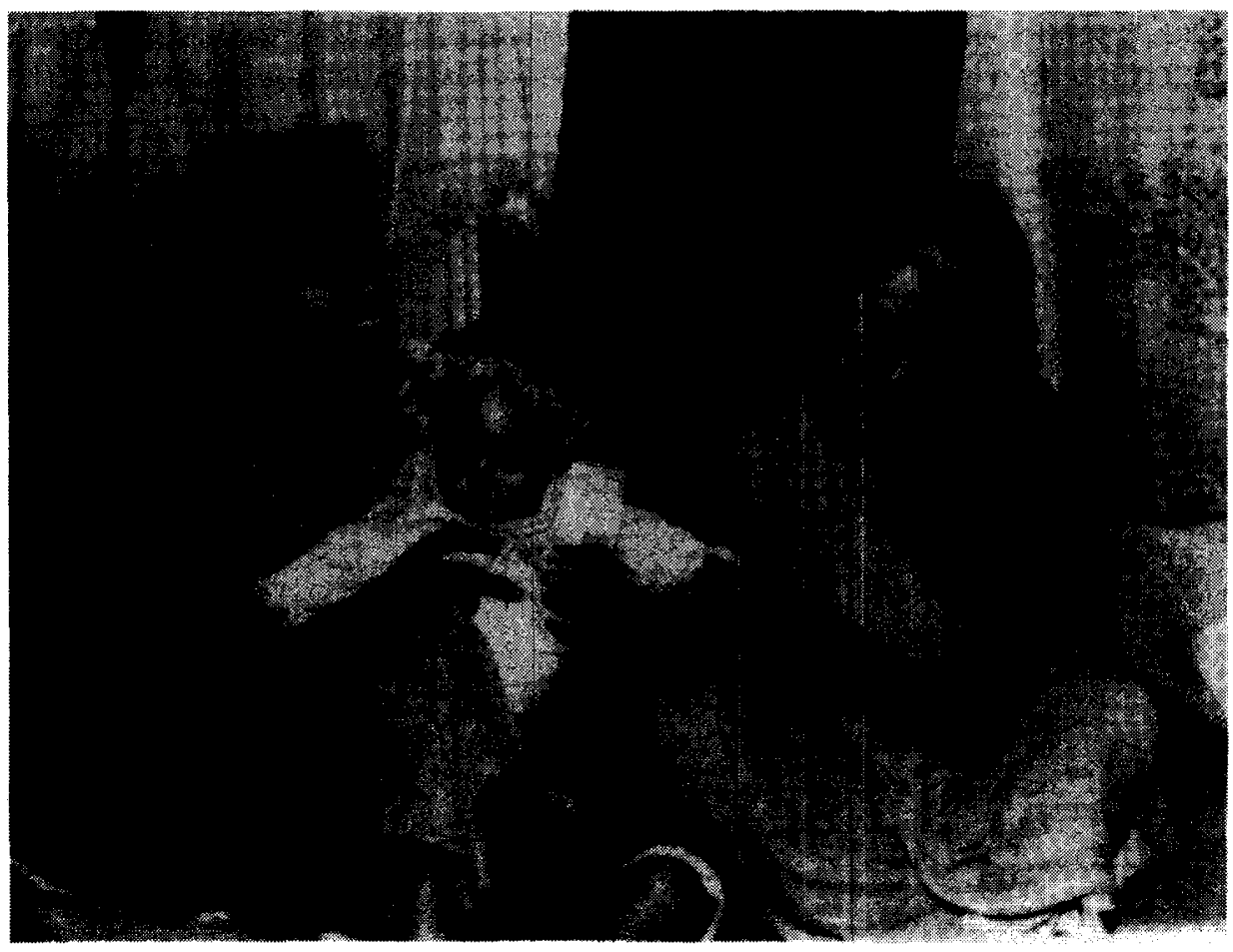

Women refugees in the camp (Photo D. Krishnan) 
Despite the UNHCR's presence and rolein rehabilitation, studies and reports by refugees on the returnee camps established the facts that the situation in Sri Lanka is not conducive to return. Refugees have gone from a camp in India to a camp in Sri Lanka. According to refugee sources in areas such as Trincomalee resettlement in urban areas has been possible, but not in rural areas. As the majority are from rural areas they continue to languish in camps. Refugees have always established their own informal channels of communication and the reports from Sri Lanka on existing conditions has not created a confidence to return (Varadakumar also provides an insight into camp conditions in Sri Lanka).

\section{Impact on host society}

The presence of the Sri Lankan Tamil has had immense influence on the host society. Its politics and society became deeply involved with the issue. A warning was sounded that sooner or later Prabhakaran and his ideology would havea "profound influence on the minds of Tamil Nadu youth, and the effect of such an influence will be a volcanic eruption which cannot be neutralized (Thillai Rajah, 7)." Though the situation is not as grave as predicted, the impact on Tamil Nadu's politics, police, bureaucracy and society has been increasingly felt.

\section{Conclusion}

The impact of the assassination of Rajiv Gandhi had far reaching consequences on the refugee. An environment was created which brought about changes both in their lifestyles and acceptance by the host country. The immediate response of the government and people was that it was difficult to differentiate between the militants and refugees so all Sri Lankan Tamils should be deported.

The support the refugee has provided to the militant either willingly or under duress has proved costly for them in the long run. In the initial euphoria of the Tamil Eelam the authentic refugee gained, but as militant and related activities increased in the state, the refugee began to suffer. In most cases it was not directly but by a negative fall out. According to many local Tamils, the local support is either by reflex or has vanished completely in some places.

The above scenario shows that the Sri Lankan Tamil is no longer welcome. But the fact is that the crisis is nowhere near resolving and the problematicissues that leave the refugee environment unchanged and that can result in further flows are many. The ethnic problem is the major issue, though in a different dimension. It is being increasingly recognized that the ethnic issue cannot be solved simply with the cessation of hostilities between the Sinhalese and the Tamils and settlement of their dispute. This is because the Tamil community is itself divided. The divide between the Sri Lankan Tamil and the Indian Tamil, the Sri Lankan Tamil and the Muslim Tamil and between the Sri Lankan Tamils themselves in the north and north east is widening.

The assassination of President Premadasa on May 1, 1993 will complicate matters and the refugees in India realize that there is no easy solution to the problem. Despite this, they themselves have provided recommendations which could bring some relief to them.

The major items on their agenda include India's continuance of a major role in settlement of issues. Having become a party, they say, it should continue to play an important part in the process of settlement. As Sinhala intransigence remains, they feel that international pressure should be applied simultaneously. In the meantime an interim arrangement to ensure security and safety of refugee returnees in Sri Lanka would facilitate discussion.

They feel that improvement in their status can result if India accedes to the United Nations Convention regarding refugees. It should also strengthen the role of the UNHCR. Repatriation on a bilateral basis without giving importance to the refugees contravenes their human rights, they say . The agreement should be, they contend, at least be tripartite with the UNHCR as a third party. It should also cover resettlement and integration of policy implementation in India and Sri Lanka.

Indian policy they maintain should be more humanitarian and less political. It should handle the refugee on a humanitarian basis alone and refugee assistance until their return should not be seen as a temporary phase. Provision of education and opportunity to gain skills be restored. It should sustain the 